\title{
ANATOMIC STRUCTURE OF FROZEN STRAWBERRIES DEPENDING ON PREVIOUS PROCESSING
}

\author{
I. Zamorska \\ Uman National University of Horticulture
}

\begin{tabular}{l}
$\quad$ Key words: \\
Freezing \\
Strawberry \\
Solution \\
Concentration \\
Microstructure \\
\hline
\end{tabular}

Article history:

Received 16.03.2018

Received in revised form

28.03.2018

Accepted 18.04.2018

Corresponding author:

I. Zamorska

E-mail:

zil197608@gmail.com

\begin{abstract}
The anatomical structure of frozen strawberries, cv. Ducat, depending on pre-treatment in potato starch solutions with concentration 1,2 , and $3 \%$ and sugar-pectin solutions with concentration 1 and $2 \%$ in equal correlation of sugar and pectin, was studied.

It has been found out that mesocarp cells of strawberries at a consumer stage have large parenchyma cells with thin membranes, large intercellular walls as thick as $50-75 \mu \kappa$, and as long as $150-225 \mu \kappa$. They are long in strawberries cv. Polka, Honey and Rusanivka, and they are round and angular-oval in Ducat strawberries. Mesocarp cells of strawberries are filled with cellular sap, and large intercellular walls - with air.

The microscopy of the received samples of frozen strawberries showed the formation of ice crystals of various sizes in intercellular space and distinct changes in the structure of parenchyma tissues, which were seen in the change of the form and the loss of integrity. Instead, epidermis cells did not lose their form and integrity. The membrane thickness on a surface in the strawberries treated with $1 \%$-starch solution was $0,1 \mathrm{~mm}$, and in those treated with 2 and $3 \%$ of starch solution - more than $0,1 \mathrm{~mm}$. The treatment of strawberries in sugar-pectin solutions of different concentrations resulted in the formation of membrane on strawberry surface - 0,05 and $0,1 \mathrm{~mm}$.

The tissue microstructure of frozen strawberries, which were pre-treated in the solutions with structure-maintaining properties, remained in a better condition, which was due to the decrease of mass loss during freezing and the prevention of cell moisture loss during defrosting.

A serious preservation of the form and structure, compared with other variants, was found when strawberries were treated in 3\% starch solution and 2\% sugar-pectin solution.
\end{abstract}

\section{АНАТОМІЧНА БУДОВА ЗАМОРОЖЕНИХ ЯГІД СУНИЦІ ЗАЛЕЖНО ВІД ПОПЕРЕДНЬОЇ ОБРОБКИ}

\author{
І.Л. Заморська \\ Уманський наиіональний університет садівництва
}

Суниця - изіна ягідна культура, щзо користується значним попитом на ринку у свіжому та замороженому вигляді. Проте під час заморожування 
ягід спостерігаються негативні зміни структури тканин, запобігти яким можна за допомогою попередньої обробки ягід перед заморожуванням.

Досліджено анатомічну будову свіжих $i$ заморожених ягід сунииі сорту Дукат, щио були попередньо оброблені перед заморожуванням у розчинах картопляного крохмалю з концентрачією 1, 2 і 3\% та в иукрово-пектинових 3 концентрацією 1 і 2\% у рівних співвідношеннях иукру та пектину.

Встановлено, що клітини мезокарпію ягід суниці в споживній стадії стиглості мають крупні паренхімні клітини з тонкими оболонками, великими міжклітинниками завширшки від 50 до 75 нк та завдовжки від 150 до $225 \mu \kappa$. Клітини мезокарпію ягід суничі заповнені клітинним соком, а великі міжклітинники - повітрям. Попередня обробка ягід суниці сприяла утворенню на поверхні ягід плівки товщиною 0,05-0,1 мм залежно від кониентрації розчину.

Під час заморожування виявлено утворення кристалів льоду всередині паренхімних тканин ягід з локалізацією їх у міжклітинному просторі. Істотне збереження форми та структури ягід встановлено у варіантах з їх обробкою у 3-процентному розчині крохмалю та 2-прочентному иукровопектиновому розчині.

Доведено, щз попередня обробка ягід сунииі перед заморожуванням у розчинах зі структуроутримуючими властивостями сприяла збереженню структури тканин завдяки утвореній на поверхні плівиі, запобігаючи витіканню клітинної вологи. Збереженість структури ягід корелювала з конщентрачією розчину для обробки.

Ключові слова: заморожування, суниця, розчин, конщентрація, мікроструктура.

Постановка проблеми. Суниця - одна із найбільш популярних і цінних ягідних культур в Україні та світі, що зумовлено іï адаптивністю до умов вирощування, високою рентабельністю виробництва, гармонійним смаком i ароматом. Заморожені ягоди суниці користуються значним попитом на світовому ринку, а до найбільших імпортерів відносять США (25\%), Німеччину (12\%), Францію (9\%), Японію (7\%) та Канаду (6\%) [1]. Експорт заморожених ягід суниці з України у 2015 р. приніс прибутку втричі більше, ніж свіжих [2].

Аналіз останніх досліджень і публікацій. Однак унаслідок заморожування соковитої рослинної сировини в ній відбуваються зміни органолептичних властивостей, що зумовлені утворенням кристалів льоду, зневодненням гідрофільних колоїдів, концентруванням водорозчинних сухих речовин і ще рядом причин, на які посилаються українські та зарубіжні вчені.

Повільне заморожування сприяє утворенню крупних позаклітинних кристалів льоду, що викликають механічні пошкодження рослинних тканин [3] i зміну транспортних властивостей клітинних мембран, внаслідок чого втрачається їхня напівпроникність. Це спричиняє втрати вологи та речовин, що розчинені в клітинному сокові [4].

Для запобігання небажаним змінам харчової, біологічної цінності та органолептичних властивостей плодоовочевої продукції у ряді досліджень 
запропоновано різні способи попередньої обробки сировини перед заморожуванням, що сприяють збереженню якості [5].

Виділення не вирішених раніше частин загальної проблеми. Окремим напрямом попередньої обробки рослинної сировини є збереження ії структури після дефростації, оскільки деякі види сировини мають високу здатність до зміни своєї форми. Для підвищення стійкості клітинної структури до замерзання використовують розчини сахарози, гідроколоїдів, кальцію та натрієвої солі, а також сумішей, що включають ці компоненти. Влив цих сполук на клітинну структуру зумовлений взаємодією 3 компонентами клітинної стінки, що сприяє зменшенню росту кристалів льоду та підтримання цілісності тканин [5].

За даними M. Suutarinen [6], структурну міцність свіжих ягід суниці зумовлюють тургор клітини, тип і кількість эї вмісту, а також характер клітинної стінки і серединної пластинки, що «цементує» окремі клітини для формування тканин [7]. Негативні зміни гістологічної структури суниці під час заморожування залежать не лише від швидкості заморожування і розмірів кристалів льоду, а й від структури окремих типів тканин у суниці. Так, під час заморожування не виявляють змін в епідермісі і ксилемі, але спостерігають незначний розрив паренхімних клітин. У ягід сортів 3 крупними клітинами негативні наслідки розривів клітин виражені сильніше [6]. Тому вивчення змін анатомічної будови заморожених ягід суниці залежно від попередньої обробки в розчинах зі структуроутримуючими властивостями $\epsilon$ актуальним.

Мета статті: дослідження впливу попередньої обробки ягід суниці в розчинах зі структуроутримуючими властивостями на зміни їхньої анатомічної будови під час заморожування.

Викладення основних результатів дослідження. Об'єктом дослідження були ягоди суниці сорту Дукат. Ягоди отримували в день збирання, сортували, видаляли чашолистки, мили, підсушували та занурювали у розчин картопляного крохмалю з концентрацією 1,2 і 3\% і в цукрово-пектиновий розчин 3 концентрацією 1 і 2\% у рівних співвідношеннях цукру та пектину. Після обробки ягоди підсушували та заморожували розсипом за температури мінус $30 \pm 1^{\circ} \mathrm{C}$. За контроль приймали ягоди суниці без попередньої обробки. Заморожену продукцію фасували у пакети з поліетиленової плівки масою 0,5 кг і зберігали протягом шести місяців за температури мінус $18 \pm 1^{\circ} \mathrm{C}$.

Дослідження анатомічної будови свіжих i заморожених ягід суниці здійснювали за допомогою мікроскопа «Біолам» С1У4.2. Зрізи отримували за допомогою мікротому М3-1 із пристосуванням ТОС-2. Отримані зображення фіксували на комп'ютері з допомогою відеоприставки «Philips ToUcam camera» і системи для мікроскопії й аналізу «Image Scope Lite». Для отримання забарвлення плівки на фото, ягоди, призначені для мікроскопії, занурювали у розчини із структуроутримуючими властивостями, попередньо забарвлені харчовим барвником Е142.

На рис. 1 представлені зрізи паренхімних клітин свіжих і заморожених ягід суниці, де видно, що клітини мезокарпію ягід суниці в споживній стадії стиглості мають крупні паренхімні клітини з тонкими оболонками, великими 
міжклітинниками завширшки від 50 до $75 \mu \kappa$, та завдовжки від 150 до $225 \mu \kappa$. У ягід суниці сортів Полка, Хоней і Русанівка вони продовгуватої форми, а у ягід сорту Дукат - округлої та кутасто-овальної. Клітини мезокарпію ягід суниці заповнені клітинним соком, а великі міжклітинники - повітрям, що спричиняє формування ніжної консистенції ягід.

Мікроскопія отриманих зрізів заморожених ягід суниці показала формування кристалів льоду різної величини у міжклітинному просторі та виражені зміни в структурі паренхімних тканин (рис. 1), що виявлялися видозмінами форми та втратою цілісності клітин.

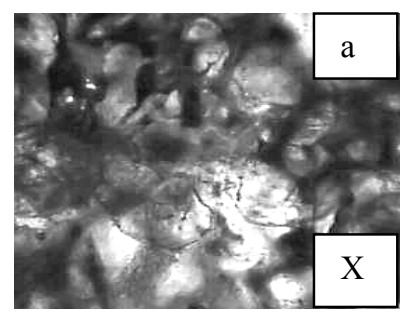

$f^{0}$

$300 \mu \kappa$

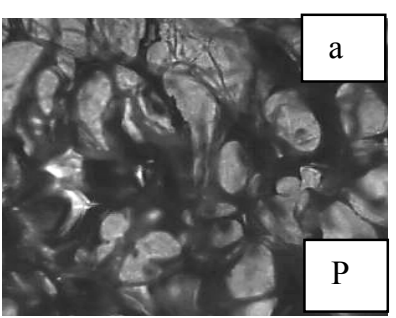

$-10$

$300 \mu \kappa$<smiles>O=CC1CCC1</smiles>

$300 \mu \kappa$
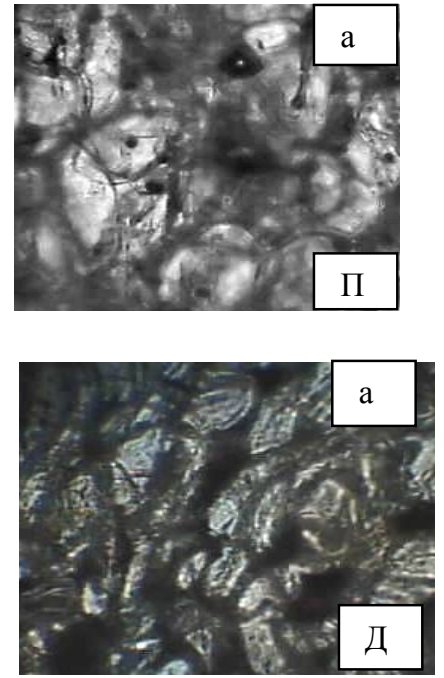

$300 \mu \kappa$

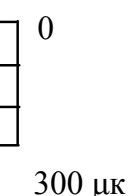

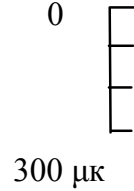

Рис. 1. Паренхімні клітини: а - свіжих і б - заморожених ягід суниці сортів: $\mathrm{X}$ - Хоней, $\mathrm{P}$ - Русанівка, П - Полка, Д - Дукат. Збільшення в 56 разів. Ціна поділки становить $100 \mu \kappa$ 
Окрім цього, виявлено потоншення клітинних стінок, що S.S. Roy, T.A. Taylor i H.L. Kramer [7] пояснюють деполімеризацією і руйнуванням пектинових речовин у клітинній стінці і серединній пластинці. Ці процеси спричиняють погіршення споживних властивостей заморожених ягід суниці, зокрема розслаблення консистенції, втрату тургору тканин, зниження кріорезистентності та значні втрати компонентів хімічного складу.

На рис. 2 і 3 представлені зрізи поверхні та паренхімних клітин свіжих і заморожених ягід суниці з обробкою в розчинах зі структуроутримуючими властивостями. 3 рисунків видно, що клітини епідермісу не втратили своєї форми та цілісності. Це збігається з даними, отриманими 3.А. Дербеденєвою [8], яка зазначає, що під час заморожування ягід суниці краще зберігається структура мілкоклітинних тканин (епідерміс, серцевина) зі щільно прилеглими одна до одної клітинами.
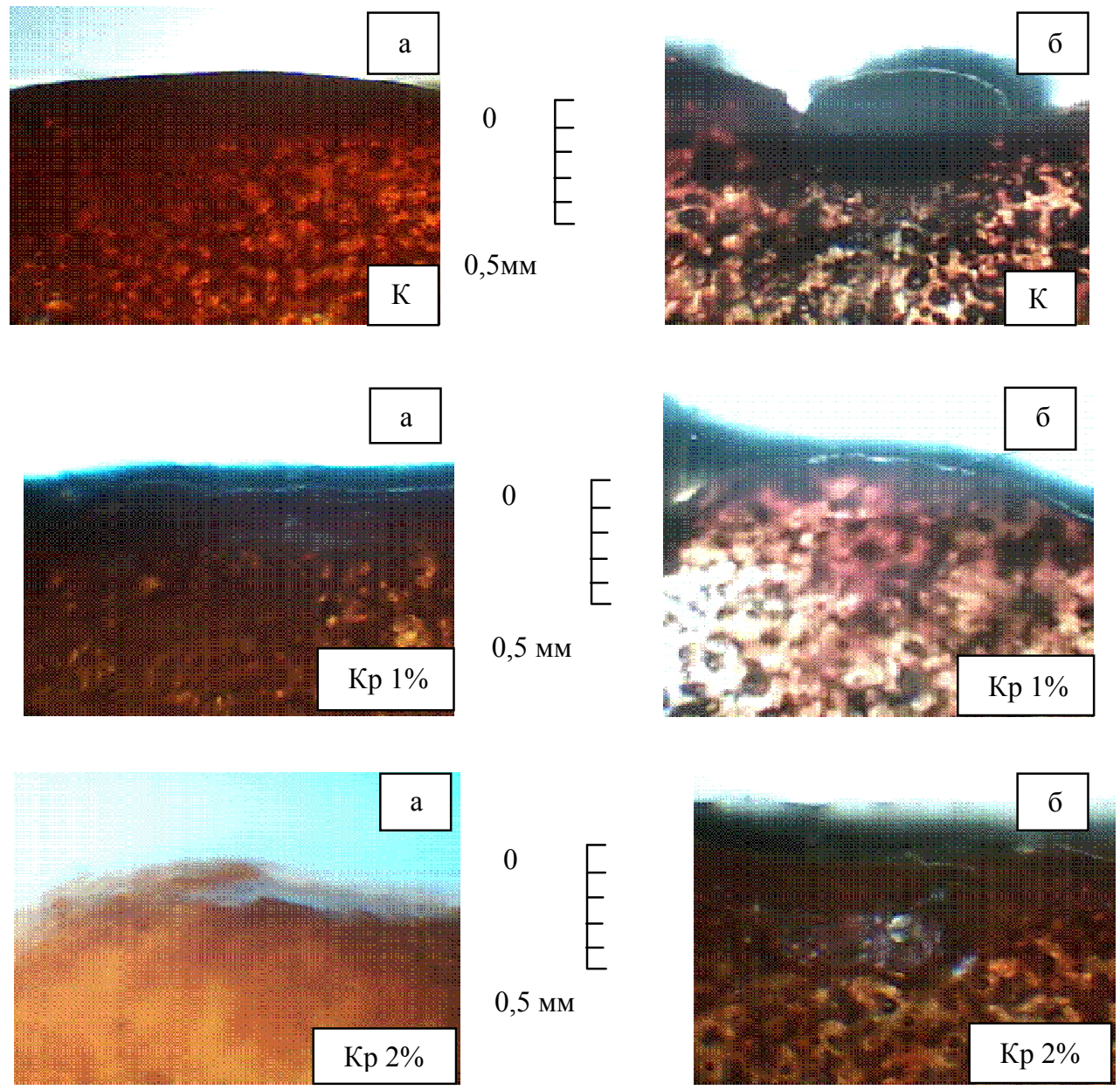

Рис. 2. Поверхня та паренхімні клітини: а - свіжих і б - заморожених ягід суниці 3 обробкою в розчинах зі структуроутримуючими властивостями. К - контроль, Кр $1 \%-1$-процентний розчин крохмалю, Кр $2 \%-2$-процентний розчин крохмалю. Збільшення в 27 разів. Ціна поділки становить 0,1 мм 
За рахунок попередньої обробки на поверхні ягід суниці утворювалася плівка різної товщини. Так, у ягід суниці, оброблених у 1 -процентному розчині крохмалю товщина плівки не перевищувала 0,1 мм. Натомість обробка ягід у 2- та 3-процентному розчині крохмалю сприяла утворенню плівки товщиною більше 0,1 мм. Обробка ягід суниці в цукрово-пектинових розчинах різної концентрації зумовила утворення на поверхні ягід плівки розміром 0,05 та 0,1 мм.

У результаті заморожування ягід суниці та подальшої їх дефростації плівка на поверхні ягід не зазнала істотних змін. А всередині паренхімних тканин ягід спостерігалося утворення кристалів льоду з локалізацією їх у міжклітинному просторі.
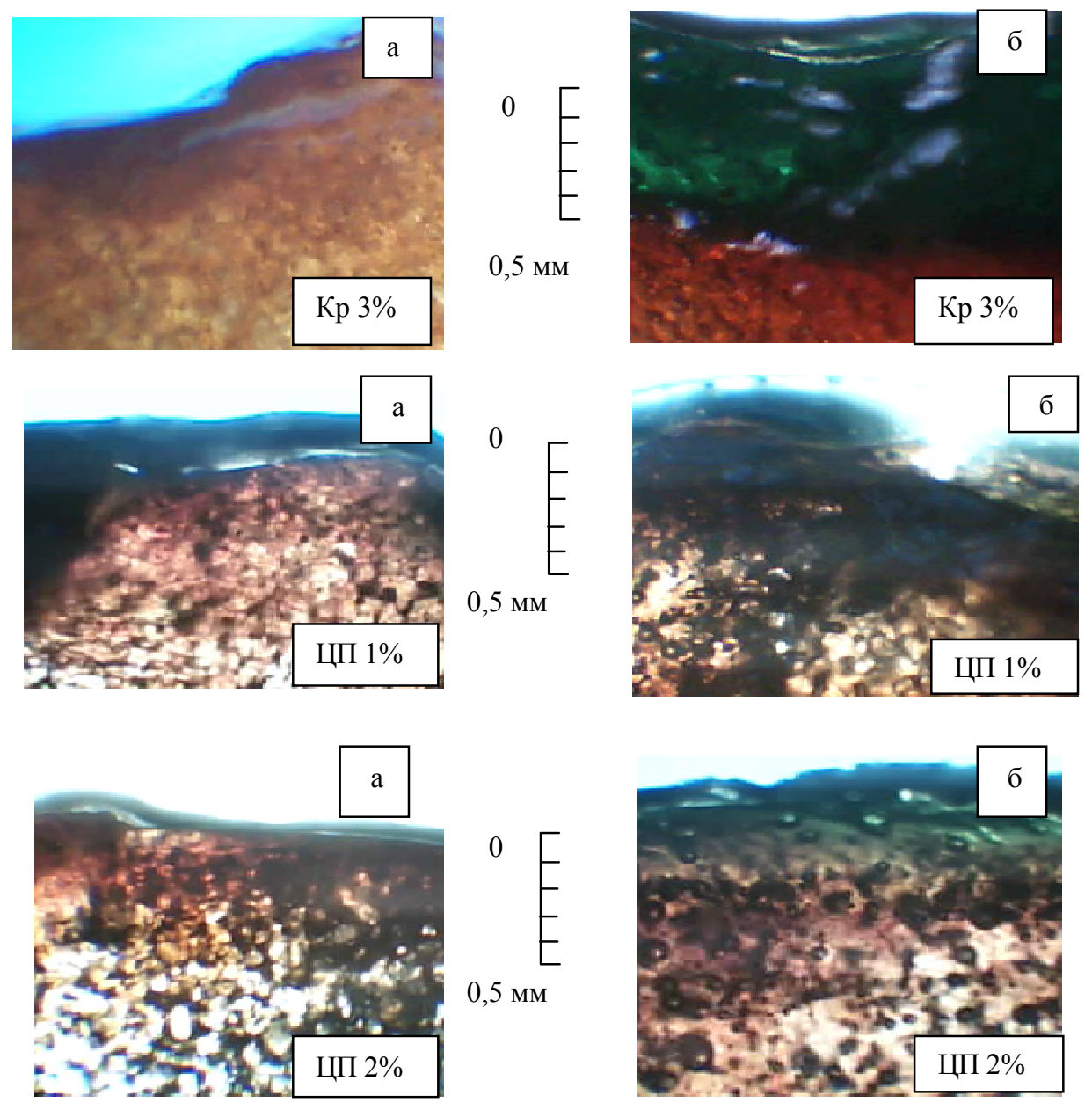

Рис. 3. Поверхня та паренхімні клітини: $\mathbf{a}-$ свіжих і б - заморожених ягід суниці 3 обробкою в розчинах зі структуроутримуючими властивостями.

Кр 3\% - 3-процентний розчин крохмалю, ЦП 1\% - 1 -процентний цукрово-пектиновий розчин, ЦП $2 \%-2$-процентний цукрово-пектиновий розчин. Збільшення в 27 разів. Ціна поділки становить 0,1 мм 
3 рис. 3 видно, що мікроструктура тканин заморожених ягід суниці, які були попередньо оброблені в розчинах зі структуроутримуючими властивостями, збереглася краще, що зумовлено зниженням втрат маси під час заморожування та запобігання втратам клітинної вологи під час дефростації.

Причому поліпшення якості ягід знаходилося в прямій залежності від концентрації розчину для обробки. Істотне збереження форми та структури ягід встановлено у варіантах 3 їх обробкою у 3 -процентному розчині крохмалю та 2-процентному цукрово-пектиновому розчині.

Очевидно, що з підвищенням концентрації крохмалю й пектину в розчині зменшується втрата клітинної вологи та збільшується захисний потенціал тканин. Подібні результати отримані за вакуумного зневоднення ягід суниці в розчинах пектину та хлориду кальцію різної концентрації [3].

\section{Висновки}

Під час заморожування ягід суниці відбувалися зміни їхньої мікроструктури, що залежать від особливостей будови тканин і зумовлені утворенням кристалів льоду в міжклітинному просторі, потоншенням клітинних стінок унаслідок руйнування пектинових речовин у клітинній стінці і серединній пластинці. Попередня обробка ягід суниці перед заморожуванням у розчинах зі структуроутримуючими властивостями сприяла збереженню структури тканин завдяки утвореній на поверхні плівці, запобігаючи таким чином витіканню клітинної вологи. Збереженість структури ягід корелювала 3 концентрацією розчину для обробки.

\section{Література}

1. Краткий анализ рынка земляники в Украине за 2015-2016 годы [Електронний ресурс]. Режим доступу : http://yagodovod.com/articles/323-kratkii-analiz-rynka-zemljaniki-v-ukraineza-2015-16-gody.html.

2. Пирожок О. Рынок ягод в Украине: рекордный экспорт и растущая ликвидность [Електронний ресурс]. - Режим доступу : http://landlord.ua/rynok-yagod-v-ukraine/.

3. Fernández L. High-pressure shift freezing versus high-pressure assisted freezing: Effects on the microstructure of a food model / L. Fernández, B. Otero, P.D. // Guignon Food Hydrocolloids. — Wrexham, 2006. - V. 20. - P. 510-522.

4. Reno M.J. Microstructural changes of frozen strawberries submitted to pre-treatments with additives and vacuum impregnation / M. J. Reno, M. E. T. Prado, J. V. de Resende // Ciênc. Tecnol. Aliment. — 2011. — \# 31(1). — P. 247-256.

5. Орлова Н. Ефективні способи стабілізації харчової та біологічної цінності замороженої плодоовочевої продукції / Н. Орлова, С. Белінська // Харчова і переробна промисловість. - 2002. - № 3. - С. 247-256.

6. Suutarinen $J$. The effect of different prefreezing treatments on the structure of strawberries before and after jam making / J. Suutarinen, K. Honkapää, R.L. Heiniö [at al.] // LWT-Food Science and Technology. - 2000. — \#33(3). - P. 188-201.

7. Roy S.S. Textural and ultrastructural changes in carrot tissue as affected by blanching and freezing / S.S. Roy, T.A. Taylor, H.L. Kramer // J. Food Sci. 2001. — Vol. 66. - P. 176-180.

8. Дербеденева 3.А. Гистологические изменения растительной ткани при замораживании и размораживании ягод земляники / 3.А. Дербеденева // Холодильная техника. 1971. — № 10. - C. 36-39. 